\title{
A Case of Antiphospholipid Syndrome with Thrombosis of the Internal Jugular Vein as the Initial Presentation
}

\author{
Haruka Tanaka $^{1)}$, Keiji Tabuchii ${ }^{2)}$, Bungo Nishimura ${ }^{2)}$, \\ Masahiro Nakayama ${ }^{1)}$ and Akira Hara ${ }^{2)}$
}

We report herein on a case of antiphospholipid syndrome with the thrombosis of the internal jugular vein. A 34-year-old female presented to our department with right-side neck pain. Contrast enhanced computed tomography (CT) revealed enlargement of the right internal jugular vein, with a non-enhancing filling defect in the lumen and peripheral enhancement of the vessel wall, leading to a diagnostic of thrombosis. Additionally, serum lupus anticoagulant tested positive, thus, the diagnosis of antiphospholipid syndrome was confirmed. Subsequently, the patient was treated with intravenous antibiotics, intravenous heparin and oral warfarin. Her swelling and pain resolved slowly and she was discharged on warfarin. Follow up at 7 months has revealed no recurrence of her symptoms but persistence of her levels of lupus anticoagulant. We should be aware of the possibility of antiphospholipid syndrome in the management of thrombosis of the internal jugular vein.

Keywords : antiphospholipid syndrome, thrombosis, internal jugular vein, lupus anticoagulant, anticoagulation therapy

\section{References}

1) Harris EN, Englert H, Derve G, et al. : Antiphospholipid antibodied in acute Guillain-Barré syndrome. Lancet 10: 13611362, 1983.

2）渥美達也：抗リン脂質抗体症候群. 日血栓止血会誌 12 : 500-508, 2001.

3) Kale US and Wight RG : Primary presentation of spontaneous jugular vein thrombosis to the otolaryngologist-in three different pathologies. J Laryngol Otol 112: 888-890, 1998.

4) 三賀森学, 池永雅一, 安井昌義, 他 : 抗リン脂質抗体症候 群に併存した S 状結腸癌の 1例. 日消外会誌 44: 1624-1631, 2011.

5) Harris EN and Pierangeli SS : Primary, secondary, and catastrophic antiphospholipid syndrome: what's in a name? Semin Thromb Hemost 34: 219-226, 2008.

6）姜 錬偲, 小菅玄晴, 福本梨沙, 他：血栓症を契機に診断 された男性の原発性抗リン脂質抗体症候群の 1 例. 心臓 44: 1168-1172, 2012.

7）鏑木淳一：抗リン脂質抗体症候群における臨床像と治療. 日臨免疫会誌 31：152-158, 2008.
8) Khamashta MA, Cuadrado MJ, Mujic F, et al. : The management of thrombosis in the antiphospholipid-antibody syndrome. N Engl J Med 332: 993-997, 1995.

9）高橋雅之, 細口翔平, 表 和徳, 他 : 深部静脈血栓症を契 機に診断された男性の原発性抗リン脂質抗体症候群の一 例. 札幌病医誌 72: 195-200, 2013.

10) González G, Gutiérrez M, Ortiz M, et al. : Association of primary antiphospholipid syndrome with primary adrenal insufficiency. J Rheumatol 23: 1286-1287, 1996.

11) Holland AJ, Childs PA, Beilin J, et al. : Spontaneous thrombosis of the internal jugular vein as the initial presentation of the primary antiphospholipid syndrome. Aust N Z J Surg 66: 854855, 1996.

12) Rosove $\mathrm{MH}$ and Brewer PM : Antiphospholipid thrombosis: clinical course after the first thrombotic event in 70 patients. Ann Intern Med 117: 303-308, 1992.

13) Vianna JL, Khamashta MA, Ordi-Ros J, et al. : Comparison of the primary and secondary antiphospholipid syndrome: a European Multicenter Study of 114 patients. Am J Med 96: 3-9, 1994.
1) Department of Otolaryngology, Tsukuba University Hospital

2) Department of Otolaryngology, Faculty of Medicine, University of Tsukuba
Corresponding Author Address : Masahiro Nakayama

nnmasa@md.tsukuba.ac.jp 


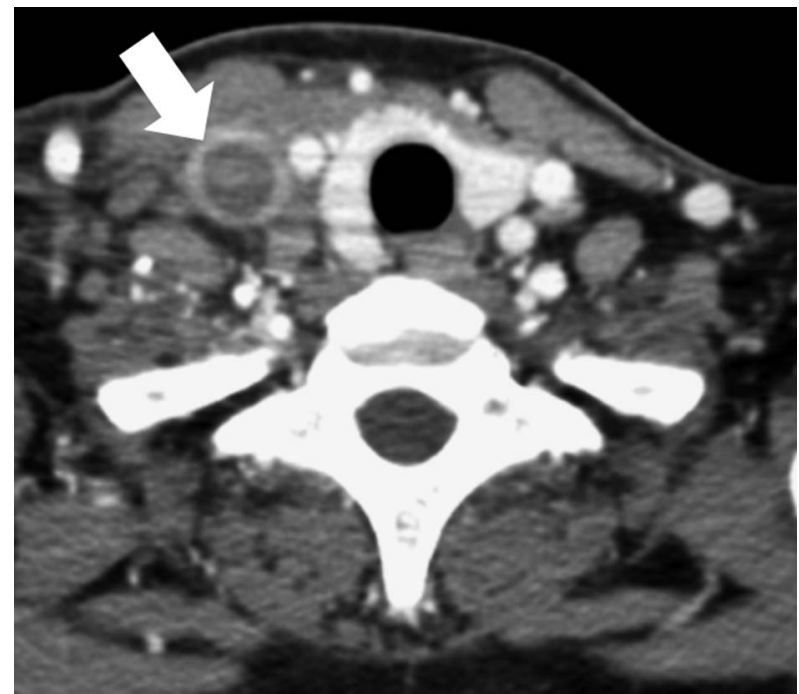

Contrast enhanced computed tomography (CT) reveals enlargement of the right internal jugular vein, with a non-enhancing filling defect in the lumen and peripheral enhancement of the vessel wall, leading to a diagnosis of thrombosis. 